\title{
Asthma and cigarette smoking
}

\author{
N.C. Thomson, R. Chaudhuri, E. Livingston
}

\begin{abstract}
Asthma and cigarette smoking. N.C. Thomson, R. Chaudhuri, E. Livingston. (C)ERS Journals Ltd 2004.

ABSTRACT: In most developed countries $\sim 25 \%$ of adults with asthma are current cigarette smokers. Asthma and active cigarette smoking interact to cause more severe symptoms, accelerated decline in lung function, and impaired short-term therapeutic response to corticosteroids.

Cigarette smoking may modify inflammation that is associated with asthma, although there is limited published data on airway pathology in smokers with asthma. To date, the evidence points towards a combination of both heightened and suppressed inflammatory responses in smokers compared with nonsmokers with asthma.

The mechanisms of corticosteroid resistance in asthmatic smokers are unexplained, but could be as a result of alterations in airway inflammatory cell phenotypes $(e . g$. increased neutrophils or reduced eosinophils), changes in the glucocorticoid receptor- $\alpha$ to $-\beta$ ratio (e.g. overexpression of glucocorticoid receptor $\beta$ ), and increased activation of pro-inflammatory transcription factors $($ e.g. nuclear factor- $\kappa \mathrm{B})$ or reduced histone deacetylase activity.

In conclusion, every effort should be made to encourage asthmatics who smoke to stop, although the effects of smoking cessation upon reversing the adverse effects of tobacco smoke on asthma control, therapeutic response to corticosteroids and airway pathology have yet to be fully elucidated. Alternative or additional therapies to inhaled corticosteroids are needed for asthmatic patients who are unable to quit smoking. Eur Respir J 2004; 24: 822-833.
\end{abstract}

Dept of Respiratory Medicine, Division of Immunology, Infection and Inflammation, University of Glasgow, Glasgow, UK.

Correspondence: N.C. Thomson

Dept of Respiratory Medicine

Division of Immunology, Infection and Inflammation

Western Infirmary \& University of Glasgow Glasgow

G11 6NT

UK

Fax: 441412113464

E-mail: n.c.thomson@clinmed.gla.ac.uk

Keywords: Asthma

corticosteroid resistance

smokers

smoking cessation

Received: April 12004

Accepted after revision: July 62004
During the mid-sixteenth century, Sir Walter Raleigh introduced tobacco to the UK, and smoking was soon recommended as a treatment of various medical complaints, including respiratory diseases. Smoking leaves and the root of the Datura plant (Datura stramonium), which contains anticholinergic compounds, was first used to treat asthma in the seventeenth century [1]. Smoking "cures" for asthma continued to be popular until the introduction of adrenaline in the 1930s. During the latter half of the last century, the harmful influence of environmental tobacco smoke on children and adults with asthma was increasingly recognised, with adverse effects being noted on the development of asthma and in aggravation of attacks [2-5]. More recently, important interactions between active cigarette smoking and asthma have been identified, including effects on morbidity, therapeutic response to corticosteroids and mechanisms of the disease (fig. 1) [6]. This review summarises published data on the clinical links between active cigarette smoking and asthma, possible biological mechanisms that could explain these links, and potential drugs to treat smokers with asthma.

\section{Prevalence of cigarette smoking}

The World Health Organization has estimated that there are $\sim 1.25$ billion smokers worldwide, with approximately two-thirds living in developing countries. In many developed countries, at least one in four adults smoke cigarettes. The prevalence of smoking in USA and UK males is 26 and $27 \%$,

For editorial comments see page 720. respectively, and, 21 and $25 \%$, respectively, in females [7, 8]. The total percentage of smokers varies between European countries, e.g. 38\% in Germany, 30\% in France, 29\% in Italy and $18 \%$ in Sweden. Prevalence rates of smoking are higher in those countries with lower incomes and among young adults, particularly females [8]. Smoking rates are, in general, much higher in underdeveloped countries. Former smokers accounted for $27 \%$ of the male and $21 \%$ of the female population in the UK [8].

There is much less information on smoking rates in adult asthmatic patients, but active cigarette smoking is common, with prevalence rates similar to the general population. Current smoking rates among asthmatic patients from the USA and UK range from 17-35\% [9-15]. In the USA, particularly high rates were found in adults presenting to hospital emergency departments with acute asthma [12]. An additional number of adult asthmatics are former smokers, with prevalence rates ranging from $22-43 \%[9,10]$. Thus, in most developed countries, at least one-half of the adult asthmatic population are likely to be current or former cigarette smokers.

\section{Development of asthma in smokers}

Active cigarette smoking has been associated with the development of asthma in some [16-19], but not all studies $[20,21]$. In asymptomatic teenagers, the development of asthma-like symptoms over a 6-yr period was independently associated with active tobacco smoking (odds ratio (OR) $(95 \%$ confidence interval $(\mathrm{CI})(2.1(1.2-3.8))$, as well as atopy 
Clinical effects

in asthma

\section{$\uparrow$ Symptoms of asthma $\uparrow$ Severity $\downarrow$ Quality of life $\downarrow$ Self-management}

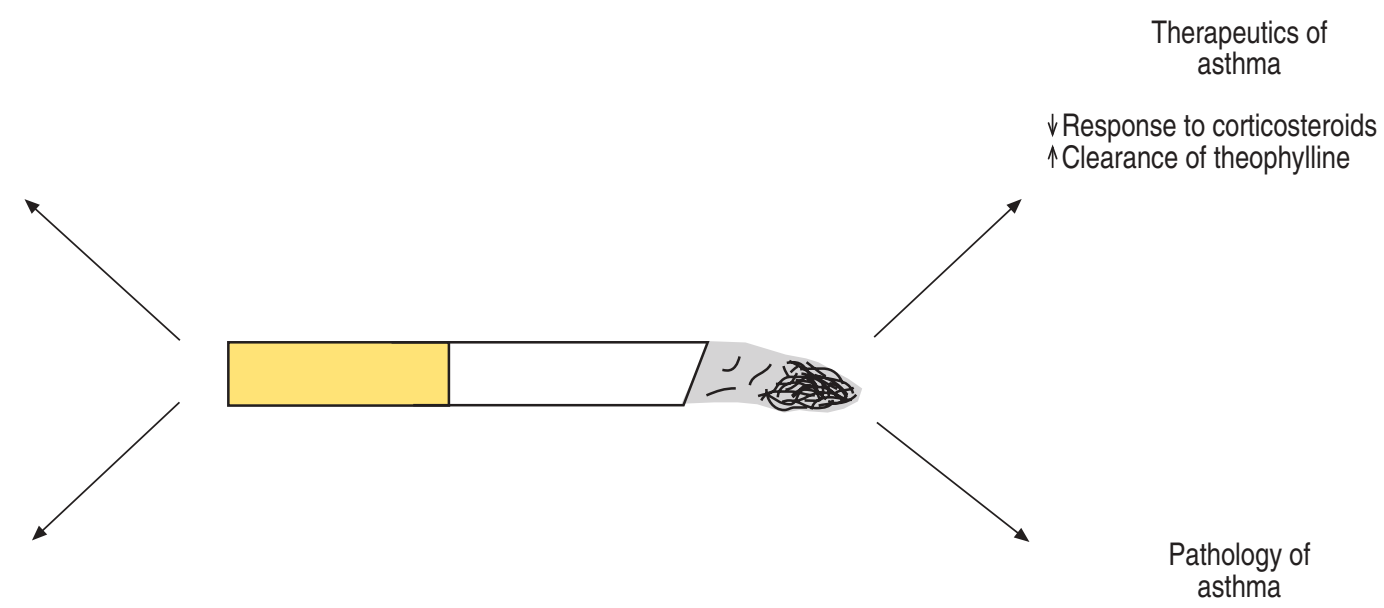

$\uparrow$ Acute bronchoconstriction $\uparrow$ Decline in FEV 1

Altered airway inflammation

Fig. 1. - Interactions between asthma and cigarette smoking. FEV1: forced expiratory volume in one second; $\uparrow:$ increase; $\downarrow:$ decrease

and bronchial hyperresponsiveness to methacholine [17]. In a retrospective study of a random population sample of 15,813 adults who were screened using a respiratory questionnaire, tobacco smokers had an increased incidence rate OR $(95 \%$ CI) of 1.6 (1.1-2.2) compared with never-smokers for adult-onset asthma in females, but not amongst males [19]. Smoking was found to be strongly associated with the onset of asthma among nonatopic individuals (5.7 (1.7-19.2)) [16], and is a risk factor for asthma among older adults (4.8 (2.3-10.1)) [18]. The $\beta_{2}$-adrenergic receptor gene polymorphism, arginine-14 genotype, confers an increased risk of asthma (7.8 (2.07-29.5)) in ever-smokers compared with neversmoking glycine-16 homozygotes [22].

Different asthma phenotypes may be related to the onset of smoking [23]. In a study of risk factors associated with asthma and the onset of cigarette smoking, asthma that developed before starting smoking was associated with atopy, whereas asthma that developed after initiating smoking was associated with a lower forced expiratory volume in one second (FEV1) [23].

\section{Clinical features}

\section{Asthma control and severity}

Both morbidity and mortality from asthma are increased in individuals who are cigarette smokers compared with neversmokers. Asthmatic smokers have more severe asthmatic symptoms [9, 10], greater need for rescue medication [24] and worse indices of health status when compared with neversmokers [11, 24]. Smoking a cigarette can cause acute bronchoconstriction, although tobacco smoke does not act as an acute irritant in all patients [25]. Baseline FEV1 is directly related to the immediate response to inhaling cigarette smoke [26], suggesting that asthmatic smokers with poorer lung function may be particularly susceptible to the acute effect of tobacco smoke. Smokers compared with nonsmokers with atopic asthma are less responsive to inhaled adenosine, which may point towards differences in airway inflammation [27].

Emergency department visits as a result of exacerbations of asthma occur more frequently amongst heavy cigarette smokers with asthma following days with high levels of ambient ozone pollution [28]. Current smoking rates are similar in patients presenting with severe exacerbations of asthma to an emergency department, whether symptoms develop within $3 \mathrm{~h}$ or at a slower onset [29]. Admission rates to hospital for asthma and hospital-based care are increased in smokers $[11,30]$, although possibly not in younger adults [31]. There is conflicting evidence as to whether current smoking is a risk factor for near-fatal asthma or fatal asthma [13, 32-34]. However, the 6-yr mortality rate is higher for smokers than nonsmokers following a near-fatal asthma attack, with an age-adjusted OR (95\% CI) of 3.6 (2-6.2) [35].

\section{Decline in lung function}

Cigarette smoking and asthma combine to accelerate the decline in lung function to a greater degree than either factor alone $[15,36]$. The Copenhagen City Heart Study included longitudinal measurement of FEV1 over a 15-yr period, and found that the average decline in FEV1 was greater in asthmatic smokers than nonsmokers [36]. The average annual decline in FEV1 in asthmatic males aged $40-59$ yrs was $33 \mathrm{~mL}$ in nonsmokers $(\mathrm{n}=36)$ and $58 \mathrm{~mL}$ in smokers $(\mathrm{n}=150$; $\mathrm{p}<0.001$ ) [36]. The presence of chronic mucus hypersecretion and smoking was associated with a greater decline in FEV1 [36]. A study of 4,000 adults initially aged 18-30 yrs, which was followed-up over 10 yrs with serial spirometry measurements, found that the decline in FEV1 was $8.5 \%$ in neversmokers without asthma $(n=2,393), 10.1 \%$ in nonsmokers with asthma $(\mathrm{n}=437)$ and $11.1 \%$ in smokers without asthma $(n=514)$. The combination of asthma and smoking $\geqslant 15$ cigarettes $\cdot$ day $^{-1}(n=101)$ had a synergistic effect on the decline in lung function, and resulted in a $17.8 \%$ decline in FEV1 over 10 yrs [15].

\section{Therapeutic response to corticosteroids}

International guidelines of asthma management emphasise inhaled corticosteroids as the most effective anti-inflammatory therapy for chronic asthma [37]. The evidence for this recommendation is based on clinical studies that have been undertaken largely in asthmatic patients who have never 
smoked or were former smokers. Several studies have suggested that the efficacy of corticosteroids is reduced in asthmatics who are active cigarette smokers [38-41], although this conclusion is not supported in another study [42]. In 1993, KERSTJENS et al. [38] reported the results of a randomised controlled trial in patients with mild-to-moderately severe obstructive airways disease (asthma and chronic obstructive pulmonary disease (COPD)), which was designed to identify factors that predicted a therapeutic response to inhaled corticosteroids. A history of current smoking predicted an impaired FEV1 response to inhaled beclomethasone $800 \mu \mathrm{g}$ q.d. at 3 months of $382 \mathrm{~mL}$ compared with nonsmokers. However, it is not clear whether it was asthmatic smokers, patients with COPD or both groups who were resistant to inhaled corticosteroids. A post hoc analysis of a randomised clinical trial designed to study the long-term effects of inhaled budesonide $(400 \mu \mathrm{g}$ q.d. or $1,600 \mu \mathrm{g}$ q.d.) or theophylline (600 $\mathrm{mg}$ q.d.) on blood markers of inflammation and lung function in asthma noted that the efficacy of inhaled budesonide was present in the nonsmoking asthmatic patients, but not in asthmatics who smoked [39]. There was no improvement in lung function or eosinophil markers in the smokers, even after 9 months of high-dose inhaled budesonide.

The effect of treatment with inhaled fluticasone propionate $(1,000 \mu \mathrm{g}$ q.d.) or placebo for 3 weeks was studied in corticosteroid-naïve adult asthmatic patients by means of a randomised placebo-controlled crossover study [40]. All of the subjects had asthma with evidence of bronchial hyperreactivity. Nonsmokers had a significant increase in mean morning peak expiratory flow (PEF; fig. 2), mean FEV1 and geometric mean provocative concentration causing a $20 \%$ fall in FEV1 (PC20) of methacholine, and a significant decrease in sputum eosinophils following fluticasone compared with placebo. These outcome measures showed no significant changes in the smoking asthmatics. A randomised parallel group study with inhaled fluticasone propionate $(2,000 \mu \mathrm{g}$ q.d.) or placebo for 6 weeks examined the effects on airway responsiveness to methacholine in 52 treatment-naïve adult asthmatic patients, of whom approximately one-half were current smokers [42]. Inhaled fluticasone decreased geometric mean PC20 of methacholine compared with placebo (1.9 doubling of PC20). Multiple linear regression analysis showed that current smoking did not influence the magnitude of the effect of inhaled fluticasone on PC20 of methacholine.

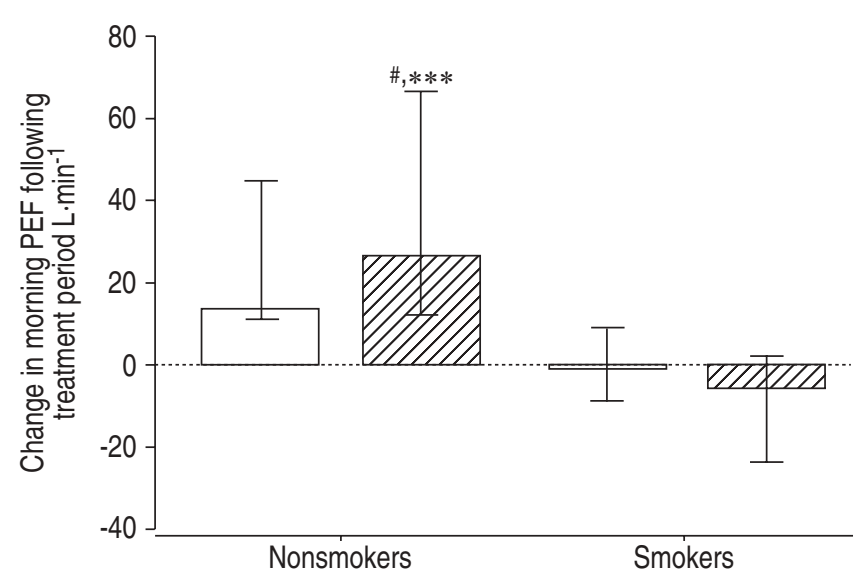

Fig. 2. - Mean ( $95 \%$ confidence interval) change in peak expiratory flow $\left(\mathrm{PEF} ; \mathrm{L} \cdot \mathrm{min}^{-1}\right.$ ) in nonsmoking and smoking asthmatic patients, following treatment with inhaled placebo $(\square)$ or fluticasone propionate $\left(\mathbb{Z} ; 1,000 \mu \mathrm{g} \cdot \mathrm{day}^{-1}\right)$. ${ }^{\#}: \mathrm{p}=0.016$, greater than nonsmokers after placebo; ***: $\mathrm{p}=0.001$, greater than smokers after fluticasone. Reproduced with permission from [40].
The efficacy of short-term oral corticosteroid treatment is impaired in chronic stable asthmatic smokers [41]. The effect of prednisolone $40 \mathrm{mg}$ q.d. or placebo for 2 weeks was studied in a randomised controlled crossover trial of asthmatic smokers, ex-smokers and never-smokers. All of the subjects had clinical asthma with evidence of reversibility in FEV1 after inhaled salbutamol of $\geqslant 15 \%$ and a mean postbronchodilator FEV1 \% predicted $>80 \%$. There was a significant improvement following oral prednisolone compared with placebo in FEV1, morning PEF and asthma control score in asthmatic never-smokers, but no change in asthmatic smokers (fig. 3). Current smoking is a predictor of impaired responses to inhaled or oral corticosteroid treatment, as assessed by improvement in FEV1, but not for changes in PC20 or asthma quality of life in mild unstable asthma [43]. Interestingly, in patients with COPD, current smoking is the factor that is most strongly associated with a reduced change in FEV1 after prednisolone [44].

Taken together, the results of these clinical studies suggest that smokers with asthma can be resistant to the beneficial therapeutic effects of corticosteroids. There are several clinical factors that might influence the response to corticosteroids in asthmatic smokers. These include:

Diagnosis. Smoking is the major factor in the development of COPD. The asthmatic smokers in these studies had several clinical features that are distinct from subjects with COPD
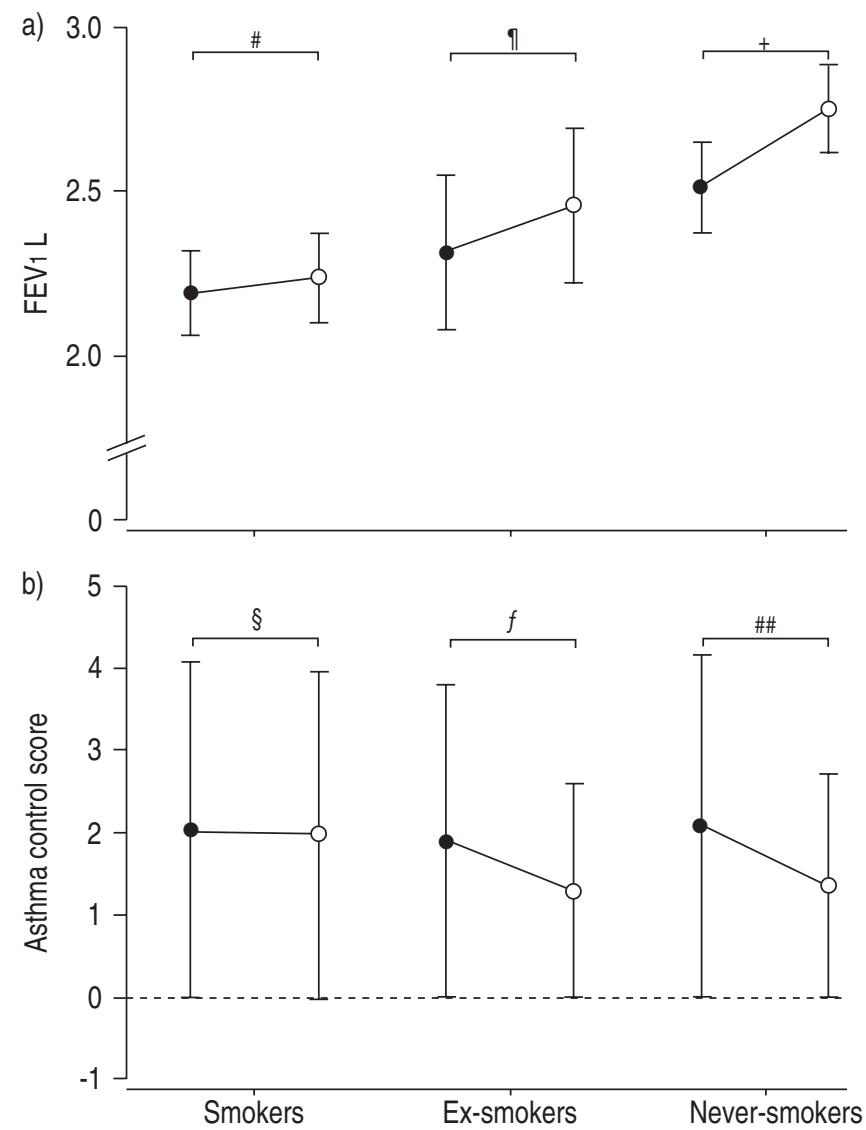

Fig. 3. - Mean difference (95\% confidence interval) after placebo ( and after prednisolone $(\bigcirc)$ in smokers with asthma, ex-smokers with asthma, and never-smokers with asthma for a) change in forced expiratory volume in one second $\left(F E V_{1}\right)$, and b) asthma control score. A reduction in the score implies an improvement in asthma control. ${ }^{\#}: \mathrm{p}=0.605 ;{ }^{\uparrow}: \mathrm{p}=0.386 ;{ }^{+}: \mathrm{p}=0.019 ;{ }^{\S}: \mathrm{p}=0.865 ;{ }^{f}: \mathrm{p}=0.108 ;{ }^{\# \#}$ : $\mathrm{p}=0.04$. Reproduced with permission from [41]. 
[40, 41], as they were younger than subjects typically associated with symptomatic COPD [40, 41] and had a long history of asthma. In addition, the patients had evidence of bronchial hyperreactivity to methacholine [40] or reversibility following salbutamol of $\geqslant 15 \%$ [41].

Duration of inhaled corticosteroid therapy. It remains to be established whether duration of therapy might influence the response to inhaled corticosteroids. Both the short-term randomised controlled study by CHALMERs et al. [40], in which inhaled fluticasone was administered for 3 weeks, and the more long-term trial by PEDERSEN et al. [39], in which inhaled budesonide was administered for 9 months, showed corticosteroid resistance in smokers. These studies used symptoms and lung functions to assess the response to drug therapy, and it is possible that administration of inhaled corticosteroid for a long duration might have beneficial effects on other clinical endpoints including exacerbation rates.

Intensity of smoking. Previous work on resistance to inhaled corticosteroids in asthmatic smokers has recruited individuals with a moderately heavy smoking pack history of $\geqslant 10 \mathrm{yrs}$ $[40,41,45]$. It is not known whether the response to corticosteroids is also decreased when the smoking history is of a lower intensity. In a study that reported that current smoking did not influence the magnitude of the effect of inhaled fluticasone on PC20 of methacholine [42], the asthmatics smoked at least five cigarettes daily, but more detail on the intensity of smoking history was not provided. Thus, it remains to be determined whether corticosteroid resistance occurs only in patients with a moderate-to-high smoking history or if it is a feature of all asthmatic smokers.

Duration of asthma. It is unclear whether smokers with recently developed asthma are resistant to corticosteroids.

\section{Metabolism of theophylline in smokers}

Cigarette smoking increases the clearance of drugs by induction of several metabolising enzymes [46]. Cytochrome P450-1A2 is responsible for the metabolism of theophyllines, and clearance is increased by $60-100 \%$ in smokers compared with nonsmokers. Smoking cessation for 1 week reduces the elimination of theophylline by $35 \%$.

\section{Patient education and self-management}

Current smokers are less likely to use appropriate methods to manage both acute and chronic asthma [47, 48]. A study of patients presenting with acute asthma to emergency departments in the USA found that current smoking was a predictor for lack of asthma knowledge and self-management skills [48]. A community-based study in the UK found that smokers with chronic asthma were less likely than nonsmokers to use inhaled corticosteroids or peak flow meters, and to alter treatment during an exacerbation [47]. Smokers with asthma are less likely to attend asthma education programmes [49-51]. In an outpatient-based study of 125 asthmatics adults, only $4 \%$ of smokers, compared with $31 \%$ of former smokers and $65 \%$ of never-smokers, completed an asthma education programme [49].

\section{Smoking cessation}

The harmful effect of active cigarette smoking in asthma reinforces the need for smoking cessation, even in those with mild disease. However, many adult smokers with asthma do not believe that they are personally at risk from their smoking [52]. In a study of a group of ever-smokers with asthma, the median time until smoking cessation was $17 \mathrm{yrs}$ [53]. The factors that predicted a longer time until smoking cessation were low educational level, higher intensity of smoking, starting smoking at an early age and asthma developing in late childhood [53]. In the general population, smokingcessation interventions using brief opportunistic advice, behavioural support, nicotine replacement therapy or bupropion are all effective, although only a minority of smokers successfully quit each year [54]. These interventions have not been studied specifically in an asthmatic population, although their efficacy is likely to be similar to the general population of current smokers.

Smoking cessation in nonasthmatic subjects reduces respiratory symptoms, such as cough and sputum production, and the frequency of respiratory infections [55, 56]. Pulmonary function improves by $\leqslant 5 \%$, and the rate of decline in lung function returns to that of never-smokers [57]. Smoking cessation is likely to produce similar clinical benefits in asthmatic smokers, although there is limited data available. A cross-sectional study of 27 current smokers and 27 exsmokers found that the latter group had lower levels of chronic cough and phlegm [25]; however, in another study, the asthma-symptom score was similar between a small group of smokers and ex-smokers with asthma [41]. A study of 59 adult asthmatics who stopped smoking reported that 18 $(30.5 \%)$ complained of worsening symptoms [58]. FENNERTY et al. [59] reported that two out of 14 asthmatic patients complained of increased symptoms within $24 \mathrm{~h}$ of smoking cessation, but that four out of seven were less symptomatic 1 week after quitting. The effect of smoking on corticosteroid responsiveness may be partially reversible, since former smokers, unlike current smokers, show improvements in morning PEF values following oral corticosteroid treatment [41].

The risk of developing self-reported asthma in former smokers compared with never-smokers is increased after smoking cessation $[21,58,60]$, but decreases with time after smoking cessation [21]. This effect is not thought to be causal, but rather as a result of individuals attributing symptoms of COPD to asthma, or as a result of smokers who stop smoking because of the onset of respiratory symptoms and are later diagnosed with asthma [21, 60].

\section{Biological mechanisms}

\section{Airway pathology}

Cigarette smoking may modify inflammation associated with asthma; however, there is limited data on the influence of active smoking on airway pathology in asthma.

Inflammatory cell phenotypes. Cigarette smoking induces airway inflammation in nonasthmatic smokers without airflow obstruction compared with nonsmokers [61-64]. Normal smokers show increased T-lymphocytes, mainly CD8+ cells [65] and macrophages numbers within the airway wall, higher neutrophil numbers within bronchial secretions [61], and infiltration of peripheral airways with mononuclear cells and macrophages [61]. The peripheral lung sections from smokers have been reported to have increased numbers of eosinophils infiltrating the submucosa compared with nonsmokers [66].

There are no published studies on the histology of airway inflammation in smokers with asthma assessed by either 
bronchial biopsies or lung-resection specimens. Induced sputum eosinophil counts are reduced in smokers, compared with nonsmokers, with mild asthma [45]. The reasons for a reduction in sputum eosinophil counts in asthmatic smokers have not been elucidated [6], but could be explained by exogenous nitric oxide (NO) in cigarette smoke increasing the apoptosis of activated eosinophils [67, 68]. Short-term exposure to tobacco smoke has been reported to reduce the response to ovalbumin in ovalbumin-sensitised mice and decreases bronchoalveolar lavage (BAL) eosinophil and macrophage numbers when compared with nonsmoking mice [69]. Nicotine within tobacco smoke might have secondary immunomodulatory effects on eosinophil function, by inhibiting the release of pro-inflammatory cytokines from macrophages [70, 71]. However, other studies in murine models of allergy have noted that exposure to tobacco smoke increases bronchial hyperreactivity, eosinophilia and T-helper (Th)2-cytokine response following allergen challenge [72, 73]. Induced sputum neutrophil counts were found to be elevated in smokers with mild asthma, who had a mean smoking history of 21 pack-yrs, compared to asthmatic nonsmokers [45].

Total BAL cell counts and the concentration of alveolar macrophages, lymphocytes, neutrophils and eosinophils, which are elevated in normal smokers, return to normal within 9 months of smoking cessation [74]. However, previous cigarette smoking causes persistent inflammation within the lungs of patients with COPD after smoking cessation [56, 75, 76]. Induced sputum differential cell counts and macrophage phenotypes are similar in patients with COPD who are current smokers when compared with former smokers [76]. Bronchial biopsies from current and former smokers with chronic bronchitis show similar degrees of inflammation [75]. It remains to be determined whether smoking cessation will reduce airway inflammation in smokers with asthma, as occurs in normal subjects, or whether it persists, as occurs in patients with COPD.

Cytokines and mediators. Sputum interleukin (IL)-8 levels are increased in asthmatic smokers, and the concentrations are positively related to neutrophil proportions in sputum and smoking history in pack-yrs, and negatively correlated to FEV1 $\%$ predicted [45]. These findings provide indirect evidence for an association between smoking, airway inflammation and reduced lung function in asthmatic smokers. Sputum eosinophilic protein (ECP) concentrations are similar between smokers and nonsmokers with asthma [45]. IL-18 is a cytokine that is involved in the development of Th1-lymphocyte responses and could have a regulatory role in asthma by inhibiting Th2-lymphocyte responses. Smoking is associated with a significant reduction in IL-18 levels in both normal and asthmatic subjects compared with nonsmokers, and this effect is more pronounced in asthmatics than in normal subjects [77]. IL-18 mRNA expression was reduced in asthmatic smokers compared with nonsmokers. These findings suggest that cigarette smoking may, in part, modify airway inflammation by potentially altering the balance of Th1-/ Th2-cytokine secretion. Asthmatic smokers have raised concentrations of the anti-inflammatory protein lipocortin-1 in BAL samples compared with nonsmokers with asthma [78]. These authors postulated that lipocortin-1 was elevated in smokers as a self-protecting mechanism to suppress airway inflammation.

Exhaled NO (eNO) levels are reduced in mild steroid-naïve asthmatic smokers compared with asthmatic nonsmokers [79]. Cigarette smoke may reduce eNO by inhibiting inducible NO synthase as a result of either the direct effect of the high concentration of exogenous NO [68], or by the carbon monoxide in the cigarette smoke interacting with haem proteins [80]. In normal smokers, eNO levels rise after smoking cessation [81]. Oxidative stress is enhanced in asthma, COPD and in smokers without airflow obstruction $[82,83]$. It is likely that an increased oxidative burden is a feature of smokers with asthma. Neurogenic inflammation may also contribute to airway inflammation in asthmatic smokers [84].

Airway remodelling. Airway remodelling might be more severe in asthmatic smokers, as the airway longitudinal elastic-fibre network in airway specimens obtained from asthmatics dying from causes other than asthma is increased in smokers compared with nonsmokers [85]. An increase in the area of submucosal elastic fibres could alter the mechanical properties of the airway wall. The use of high-resolution computed tomography to assess structural changes in the lungs [86, 87] has revealed that the presence of emphysema in smokers with asthma is associated with a greater smoking history [88]. Hyperinflation or emphysematous changes of the lungs are increased in asthmatic ex-smokers, who had a heavy smoking history of 49 pack-yrs, when compared with asthmatic never-smokers [89].

Circulating peripheral blood cells. Circulating peripheral blood eosinophil counts are reduced in cigarette smokers with asthma compared with never-smokers with asthma [90], whereas the converse is found in normal nonasthmatics, where current smoking is associated with increased circulating eosinophil counts [91-93]. These results point to an alteration in the inflammatory cell response in the asthmatic smokers, with suppression of the elevated circulating blood eosinophil counts that are associated with asthma. Circulating blood concentrations of myeloperoxidase and ECP are similar between asthmatic smokers compared with asthmatic nonsmokers and ex-smokers [39]. The generation of leukotriene $\mathrm{B}_{4}\left(\mathrm{LTB}_{4}\right)$ by peripheral blood leucocytes is increased in elderly patients with asthma who are smokers compared with nonsmokers [89]. Current cigarette smoking is positively associated with specific immunoglobulin E antibodies to house dust mite within the general population [94]. Thus, it is possible that cigarette smoking might influence the immunological response to allergens in asthma.

Overview of airway pathology in smokers with asthma. Taking the findings from these studies together, there appears to be a combination of both heightened and suppressed inflammatory responses in smokers compared with nonsmokers with asthma. For example, eosinophil numbers are reduced, whereas neutrophil counts are raised in induced sputum samples from smokers with asthma. Some cytokine concentrations, such as IL-8, are raised and others, such as IL-18, are suppressed by cigarette smoking. It is unclear whether these changes in cell number and cytokine concentrations are important in the pathogenesis of the heightened symptom severity found in smokers with asthma. Alternatively, these changes may reflect the duration and intensity of the smoking history, but may not be directly relevant to the mechanisms of disease in asthmatic smokers. Further studies using both invasive and noninvasive techniques are required to assess cellular and structural changes in the airways of asthmatic smokers compared with asthmatic nonsmokers and COPD sufferers. In particular, it will be important to establish whether the airway pathology of asthmatic smokers is predominantly that of asthmatic nonsmokers, COPD, or a combination of these two conditions. 


\section{Mechanisms of corticosteroid resistance in smokers with asthma}

The anti-inflammatory effects of corticosteroids are mediated by activation of cytoplasmic glucocorticoid receptors (GRs) that act as ligand-activated transcription factors, which translocate into the nucleus to suppress or induce glucocorticoid target genes, either by directly binding to DNA sequences (transactivation) or by interacting with proinflammatory transcription factors (transrepression) [95-97]. Various mechanisms have been implicated in corticosteroid resistance in asthmatic nonsmokers and in other diseases, including inflammatory bowel disease and rheumatoid arthritis [95-99]. Potential mechanisms of corticosteroid resistance in asthmatic smokers are largely unstudied, but may include one or more of the pathways implicated in asthmatic nonsmokers and other inflammatory diseases (fig. 4; table 1).
Corticosteroid pharmacokinetics. Airway mucosal permeability in vivo is increased in cigarette smokers with normal lung function [100] and in asthmatic nonsmokers compared with normal subjects [101]. It is unknown whether there is an additive or synergistic effect of cigarette smoking and asthma on airway permeability, and if so, whether there might be heightened clearance of inhaled corticosteroids from the airways of asthmatic smokers compared with asthmatic nonsmokers. Cigarette smoking causes chronic mucus hypersecretion in both normal [102] and asthmatic smokers [36]. Excess mucus lining the airways of asthmatic smokers compared with asthmatic nonsmokers could impair access of inhaled corticosteroids to GRs on target cells within the airways. However, other mechanisms must be operating, since asthmatic smokers without symptoms of chronic mucus hypersecretion show reduced therapeutic responses to inhaled corticosteroids [40]. Furthermore, corticosteroid resistance to

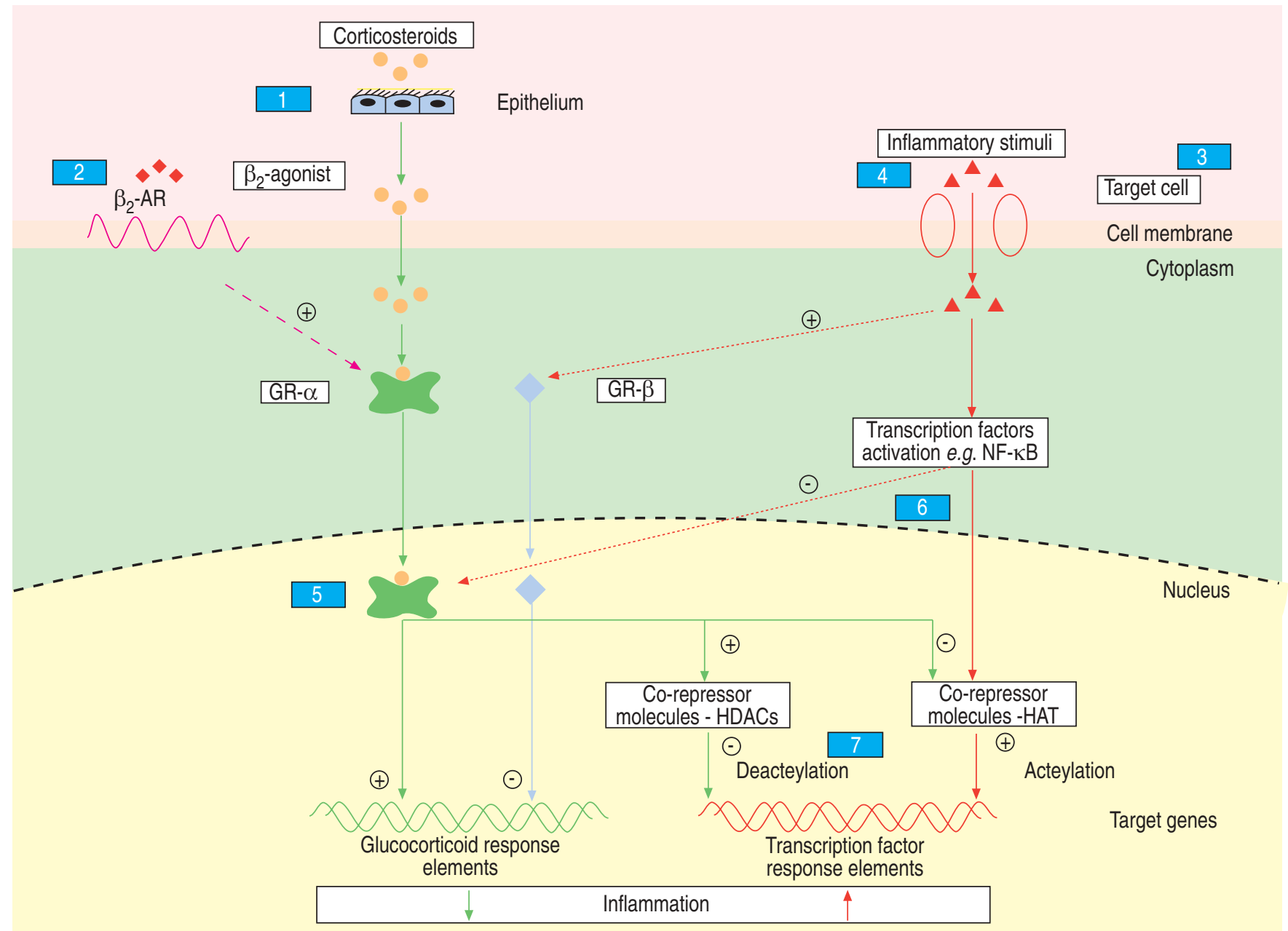

Fig. 4. - The anti-inflammatory effects of corticosteroids are mediated by activation of cytoplasmic glucocorticoid receptors (GRs) that act as ligand-activated transcription factors, which translocate into the nucleus to suppress or induce glucocorticoid target genes. GR- $\alpha$ acts by directly binding to DNA sequences (transactivation) or by interacting with pro-inflammatory transcription factors (transrepression). GR- $\beta$, which does not bind ligand, is predominately located in the nucleus and cannot transactivate glucocorticoid-sensitive genes. Potential pathways and mechanisms of corticosteroid resistance in asthmatic smokers include the following: 1) corticosteroid pharmacokinetics, e.g. increased airway mucosal permeability, increased bronchial secretions; 2) corticosteroid and $\beta_{2}$-adrenergic receptor ( $\beta_{2} \mathrm{AR}$ ) interactions, e.g. down-regulation of $\beta_{2} \mathrm{AR}$ function; 3) inflammatory cell phenotypes, e.g. increased airway neutrophil or CD8+ lymphocyte numbers, reduced airway eosinophil numbers; 4) cytokine and mediators levels, e.g. increased production of interleukin (IL)-4, IL-8, tumour necrosis factor- $\alpha$, decreased production of IL-10, increased nitrosative stress; 5) GRs, e.g. overexpression of GR- $\beta$, reduced expression of GR- $\alpha$; 6 ) pro-inflammatory transcription factor activation, e.g. nuclear factor- $\kappa \mathrm{B}(\mathrm{NF}-\kappa \mathrm{B})$, activator protein-1, signal transduction-activated factor; and 7$)$ corticosteroid cell-signalling systems, e.g. reduced histone deacetylase activity (HDAC), increased p38 mitogen-activated protein kinase activity. HAT: histone acetyltransferase. 
Table 1.-Potential mechanisms of corticosteroid resistance in asthmatic smokers

Corticosteroid pharmacokinetics

Increased airway mucosal permeability

Increased bronchial secretions

Corticosteroid and $\beta_{2}$-adrenergic receptor interactions

Down-regulation of $\beta_{2}$-adrenergic receptor function

Inflammatory cell phenotypes

Increased airway neutrophil or CD8+ lymphocyte numbers

Reduced airway eosinophil numbers

Cytokine and mediators levels

Increased production of IL-4, IL-8, TNF- $\alpha$

Decreased production of IL-10

Nitrosative stress

GR

Overexpression of GR- $\beta$

Reduced expression of GR- $\alpha$

Pro-inflammatory transcription factor activation

Overexpression of $\mathrm{NF}-\kappa \mathrm{B}$

Overexpression of activator protein-1

Overexpression of signal transduction-activated factor

Corticosteroid cell-signalling systems

Reduced histone deacetylase activity

Increased p38 mitogen-activated protein kinase activity

IL: interleukin; TNF: tumour necrosis factor; GR: glucocorticoid receptor; NF: nuclear factor.

orally administered prednisolone is unlikely to be affected by excess airway mucus or increased airway mucosal permeability [41]. The effect of cigarette smoking on the clearance of oral corticosteroids in asthma is unknown, but is likely to be normal, since smoking does not alter the pharmacokinetics of prednisolone, prednisone and dexamethasone in healthy male adults [46, 103].

Corticosteroid and $\beta_{2}$-adrenergic receptor interactions. Chronic cigarette smoking has been reported to reduce the density of $\beta_{2}-$ adrenergic receptors on lymphocytes, decrease ligand binding to $\beta_{2}$-adrenergic receptors and impair the formation of cyclic adenosine monophosphate [104]. These effects are reversible following 8 weeks of smoking cessation $[104,105]$. The degree of smoking-induced down-regulation of $\beta_{2}$-adrenergic receptor might vary between individuals according to their type of $\beta_{2^{-}}$ adrenergic receptor polymorphism [22]. $\beta_{2}$-agonists may potentiate the actions of corticosteroids by increasing the nuclear localisation of GRs [106]. Thus, in smokers with asthma, down-regulation of $\beta_{2}$-adrenergic receptor function might not only impair the clinical response to $\beta_{2}$-agonists, but also the beneficial effects of corticosteroids.

Inflammatory cell phenotypes. Cigarette smoke alters the number and function of airway inflammatory cells [107, 108]. The reduced sputum eosinophil count found in asthmatics who have smoked for many years compared with asthmatic nonsmokers [40, 45] might result in impaired responses to corticosteroids in smokers. Alternatively, the raised sputum neutrophil count in smokers with asthma might be poorly responsive to corticosteroid therapy [109]. However, there is conflicting data on the effects of corticosteroids on neutrophilic inflammation in asthma [110]. Inhibition by corticosteroids of T-lymphocyte proliferation of peripheral blood mononuclear cells is impaired in patients with corticosteroid-resistant asthma compared with patients with corticosteroid-sensitive asthma [111]. Cigarette smokers with normal lung function have increased numbers of CD8+ T-lymphocytes in BAL fluid, which correlate positively with the number of pack-yrs smoked [112]. It is possible that if airway CD8+ lymphocyte numbers, or activity, are increased in asthmatic smokers these cells might contribute to corticosteroid resistance, since raised CD8+ lymphocytes are also found in COPD [113], which is poorly responsive to corticosteroids.

Cytokines and inflammatory mediators. Exposure to cigarette smoke, either in vitro or in vivo, increases the production of proinflammatory cytokines, including IL-4 [114], IL-8 [115] and tumour necrosis factor (TNF)- $\alpha[115,116]$. These cytokines have been implicated in corticosteroid resistance, although the precise mechanisms are uncertain. The combination of IL-2 and IL-4, when added to T-lymphocytes in vitro, results in a reduced response to corticosteroids [117]. TNF- $\alpha$ causes corticosteroid resistance in human mononuclear cells in vitro, possibly through activation of nuclear factor- $\kappa \mathrm{B}(\mathrm{NF}-\kappa \mathrm{B})$ [118].

A defect in corticosteroid-induced synthesis by T-lymphocytes of the anti-inflammatory cytokine, IL-10, has been implicated in corticosteroid-resistant asthma [119]. IL-10 levels in sputum are reduced in normal smokers compared with healthy nonsmokers [120]. The ability of corticosteroid to induce IL-10 release is impaired in vitro by IL-2 combined with IL-4 [121]. Overall, these results suggest that suppressed IL-10 production by T-lymphocytes from asthmatic smokers could contribute to corticosteroid insensitivity.

NO is present in a high concentration in tobacco smoke [122], and, in vitro, reduces GR-ligand binding affinity [123]. It has been suggested that endogenous-generated "nitrosative stress" may cause defective corticosteroid responsiveness in asthma [124], and a similar mechanism may operate in asthmatic smokers as a result of the effects of exogenous and endogenous "nitrosative stress" induced by tobacco smoke.

Glucocorticoid receptor numbers or binding affinity. There are two naturally occurring isoforms of GR: GR- $\alpha$ is functional, and GR- $\beta$, which is not ligand binding, is predominantly located in the nucleus and cannot transactivate glucocorticoidsensitive genes. It has been suggested that overexpression of GR- $\beta$ might impair the response to corticosteroids by inhibiting the action of the ligand-activated GR- $\alpha$ [97, 125-128] Alternatively, a reduction in GR- $\alpha$ numbers has also been implicated as a mechanism for corticosteroid resistance [129]. The expression of GR- $\beta$ is increased in various cell types following exposure to pro-inflammatory cytokines and mediators that are increased by exposure to cigarette smoke. In combination, IL-2 and IL-4, but not the individual cytokines alone, increase T-lymphocyte GR- $\beta$ numbers [130]. IL- 8 causes neutrophils to increase GR- $\beta$ expression [131], and this could account for the poor response of these cells to corticosteroids. TNF- $\alpha$ disproportionately increases the expression of GR- $\beta$ over GR- $\alpha$ in Helen Lake human cervical carcinoma S3 cells [132]. A reduction in GR-binding affinity could contribute to corticosteroid resistance in smokers. Cultured human bronchial epithelial cells from smokers compared with nonsmokers possess GRs with a reduced binding affinity, although there is no difference in the number of binding sites [133]. GR-ligand binding affinity is reduced by IL-2 and IL-4 in combination in peripheral blood mononuclear cells [117, 121], by NO in mouse fibroblasts [123], and by IL-13 in peripheral blood monocytes [111]. It is unknown whether an alteration in the GR- $\alpha$ to $-\beta$ ratio or GR-binding affinity could contribute to corticosteroid resistance in smokers.

Pro-inflammatory transcription factor activation. There are likely to be multiple constituents within cigarette smoke, including bacterial lipopolysaccharide (LPS), which could possibly activate NF- $\kappa \mathrm{B}[134]$. NF- $\kappa \mathrm{B}$ is associated with the induction of multiple inflammatory cytokines, including TNF$\alpha$ and IL-8. Cigarette smokers with normal lung function show 
increased expression of $\mathrm{p} 65$, the major subunit of $\mathrm{NF}-\kappa \mathrm{B}$ in the bronchial epithelium, compared with nonsmokers [135]. GRs can block NF- $\kappa \mathrm{B}$ signalling, but conversely, NF- $\kappa \mathrm{B}$ can suppress both GR- $\alpha$ function by phosphorylation of the GR and the ability of the GR to bind to DNA [96]. NF- $\kappa$ B has been associated with corticosteroid unresponsiveness in Crohn's disease [136], and it is possible that a similar mechanism exists in asthmatic smokers where an imbalance between GR- $\alpha$ function and heightened $\mathrm{NF}-\kappa \mathrm{B}$ activity interacts to cause corticosteroid resistance. It is possible that other proinflammatory transcription factors, including activator protein-1 and signal transduction-activated transcription factors, are overexpressed in the cells of smokers [137], and these might contribute to corticosteroid resistance in asthmatic smokers.

Corticosteroid cell signalling systems. Corticosteroids require histone deacetylase (HDAC) activity for maximal suppression of cytokine induction [138]. Smokers have decreased HDAC2 activity in alveolar macrophages, possibly as a result of "nitrosative stress", and this may lead to increased inflammatory gene expression and reduced sensitivity to corticosteroids [139]. Corticosteroid resistance in COPD has been postulated to operate by this pathway [140].

Activation of p38 mitogen-activated protein kinase (MAPK) occurs more rapidly in bronchoalveolar cells stimulated by LPS from normal smokers compared with nonsmokers [141], and p38 MAPK phosphorylates GRs, and reduces corticosteroid affinity and corticosteroid-induced nuclear translocation of GRs [121]. Thus, the p38 MAPK signalling pathway might be activated in asthmatic smokers and contribute to corticosteroid insensitivity.

\section{Potential drugs to treat smokers with asthma}

Alternative or additional treatment to inhaled corticosteroids may be required for asthmatics who are unable to stop smoking or who have persistent symptoms following smoking cessation. There are no published clinical trials of noncorticosteroid therapies in asthmatic smokers, but several currently licensed drugs, as well as new drugs under development, may show efficacy in this group of patients (table 2).

The combination of a long-acting $\beta_{2}$ receptor agonist and an inhaled corticosteroid is highly effective in the treatment of asthma and, to a lesser extent, COPD [142, 143]. These two

\section{Table 2.-Potential drug treatments for asthmatic smokers}

Long-acting $\beta_{2}$ receptor agonists

In combination with inhaled corticosteroids

Theophyllines

New glucocorticoid receptor agonists

Selective phosphodiesterase- 4 inhibitors

Mediator antagonists

Leukotriene receptor antagonists

Histamine- $\mathrm{H}_{1}$ receptor antagonists

IL-2 receptor blockade

TNF- $\alpha, \mathrm{LTB}_{4}$, or IL-8 antagonists

Other anti-inflammatory therapies

IFN- $\alpha$

IL-10 agonists

Inhibitors of mitogen-activated protein kinases

$\mathrm{NF}-\kappa \mathrm{B}$ inhibitors

Macrolide antibiotics

Inducible nitric oxide blockers

Antioxidants

IL: interleukin; TNF: tumour necrosis factor; $\mathrm{LTB}_{4}$ : leukotriene $\mathrm{B}_{4}$; IFN: interferon; NF: nuclear factor. drugs may interact to potentiate the suppression of inflammation associated with both conditions [106, 144]. Thus, possibly the combination of these drugs may be of benefit in the treatment of asthmatic smokers. Low-dose theophylline activates HDAC, which is recruited by corticosteroids to suppress inflammation [145]. Theophylline reverses the suppressive effects of cigarette smoke on HDAC in vitro [146], and, thus, could potentially restore corticosteroid sensitivity in asthmatics who smoke. The efficacy of selective phosphodiesterase-4 inhibitors, such as cilomilast and roflumilast, in the treatment of COPD [147] and their inhibitory effect on neutrophil function suggests that these compounds might be effective in asthmatic smokers.

A number of selective GR agonists currently under development have more potent in vitro actions in causing the transrepression of inflammatory genes rather than the transactivation of genes, which are more associated with corticosteroid-induced side-effects [148]. The dissociated properties of these compounds make them potentially less likely to cause adverse effects, but whether these properties will influence their efficacy in the presence of corticosteroid resistance is not known.

Cigarette smoking causes a dose-related increase in urinary cysteinyl leukotriene $\mathrm{E}_{4}$ production [149], and 15-lipoxygenaseisoform activity is increased in the airways of healthy smokers [150]. These findings might point to a role for leukotriene receptor antagonists in asthmatic smokers. Histamine- $\mathrm{H}_{1}$ receptor antagonists, such as cetirizine and azelastine, attenuate the activity of $\mathrm{NF}-\kappa \mathrm{B}$ [151], and through this action might inhibit the potential adverse effects of NF- $\kappa \mathrm{B}$ on glucocorticoid sensitivity in asthmatic smokers. Preliminary results suggest that IL-2 receptor blockade can induce remission in corticosteroid-resistant ulcerative colitis [152]. Drugs that block the effects of other mediators implicated in cigarette smoke-induced airway inflammation, such as TNF- $\alpha, \mathrm{LTB}_{4}$, IL- 8 , oxidants, inducible NO and several chemokines, have potential as anti-asthma agents for the treatment of smokers who have asthma [148, 153].

Other anti-inflammatory therapies that are in development for treating corticosteroid-resistant asthma might be useful therapeutically in the treatment of asthmatic smokers. Treatment with interferon- $\alpha$ improved lung function and also increased corticosteroid sensitivity in patients with corticosteroid-resistant asthma $[154,155]$. A defect in corticosteroid-induced synthesis by T-lymphocytes of the anti-inflammatory cytokine IL-10 has been implicated in corticosteroid-resistant asthma [119], and an IL-10 agonist might be a future therapy for this group of patients. Inhibitors of p38 MAPK may have a role in treating corticosteroidresistant asthma, since this and other MAPKs reduce the activation of the GR by corticosteroids [121, 156]. Drugs targeted at inhibiting $\mathrm{NF}-\kappa \mathrm{B}$, which is activated in smokers, antioxidants to block oxidative stress, or macrolide antibiotics to down-regulate IL- 8 production could be of value in the treatment of smoking-related airway diseases [148, 153].

\section{Future directions for research}

Many research questions remain to be answered regarding the interaction between asthma and smoking, including the following. 1) Is corticosteroid resistance in cigarette smokers a systemic response or localised to the lungs? 2) Which factors influence the therapeutic response to corticosteroids in asthmatic smokers, including the duration or dose of inhaled corticosteroid therapy, the outcome used to assess efficacy, the duration or intensity of smoking history, or the duration of asthma? 3) Are systemic corticosteroids effective in treating 
smokers who have acute asthma? 4) What is the airway pathology in asthmatic smokers? 5) What are the mechanisms of corticosteroid resistance in asthmatic smokers? 6) Does smoking cessation improve asthma control and therapeutic response to corticosteroids? 7) Are alternative or additional treatments to inhaled corticosteroids effective in asthmatics who are unable to stop smoking or who have persistent symptoms following smoking cessation?

Acknowledgements. The authors would like to thank the National Health Service Education for Scotland, the Chief Scientists' Office and Asthma UK for their support. The authors would also like to thank K. McFall (Dept of Medical Illustration, Gartnavel General Hospital, Glasgow, UK) for her help.

\section{References}

1. Gandevia B. Historical review of the use of parasympatholytic agents in the treatment of respiratory disorders. Postgrad Med J 1975; 51: 13-20.

2. Cook D, Strachan D. Summary of effects of parental smoking on the respiratory health of children and implications for research. Thorax 1999; 54: 357-366.

3. Jaakkola MS, Piipari R, Jaakkola N, Jaakkola JJK. Environmental tobacco smoke and adult-onset asthma: a population-based incident case-control study. Am J Public Health 2003; 93: 2055-2060.

4. Chan-Yeung M, Dimich-Ward H. Respiratory health effects of exposure to environmental tobacco smoke. Respirology 2003; 8: 131-139.

5. Coultas D. Passive smoking and risk of adult asthma and COPD: an update. Thorax 1998; 53: 381-387.

6. Thomson N, Chaudhuri R, Livingston E. Active cigarette smoking and asthma. Clin Exp Allergy 2003; 33: 1471-1475.

7. Centers for Disease Control and Prevention. State-specific prevalence of current cigarette smoking among adults: United States, 2002. MMWR Morb Mortal Wkly Rep 2004; 52: 1277-1300.

8. UK Government. Living in Britain: results from the 2002 General Household Survey, Office for National Statistics. www.statistics.gov.uk/lib2002. Date last updated: April 20 2004. Date last accessed: June 282004.

9. Althuis M, Sexton M, Prybylski D. Cigarette smoking and asthma symptom severity among adult asthmatics. J Asthma 1999; 36: 257-264.

10. Siroux V, Pin I, Oryszcyn MP, Le Moual N, Kauffmann F. Relationships of active smoking to asthma and asthma severity in the EGEA study. Eur Respir $J$ 2000; 15: 470-477.

11. Sippel JM, Pedula KL, Vollmer WM, Buist AS, Osborne ML. Associations of smoking with hospital-based care and quality of life in patients with obstructive airway disease Chest 1999; 115: 691-696.

12. Silverman RA, Boudreaux ED, Woodruff PG, Clark S, Camargo CA Jr. Cigarette smoking among asthmatic adults presenting to 64 emergency departments. Chest 2003; 123: $1472-1479$.

13. Turner M, Noertjojo K, Vedal S, Bai T, Crump S, Fitzgerald JM. Risk factors for near fatal asthma. A case-control study in hospitalized patients with asthma. Am J Respir Crit Care Med 1998; 157: 1804-1809.

14. Walsh LJ, Wong CA, Cooper S, Guhan AR, Pringle M, Tattersfield AE. Morbidity from asthma in relation to regular treatment: a community based study. Thorax 1999; 54: $296-300$

15. Apostol G, Jacobs D, Tsai A, et al. Early life factors contribute to the decrease in lung function between ages 18 and 40. Am J Respir Crit Care Med 2002; 166: 166-172.
16. Plaschke P, Janson C, Norrman E, Bjornsson E, Ellbjar S, Jarvholm B. Onset and remission of allergic rhinitis and asthma and the relationship with atopic sensitization and smoking. Am J Repir Crit Care Med 2000; 162: 920-924.

17. Rasmussen FSHC, Lambrechtsen J, Hansen HS, Hansen NC. Impact of airway lability, atopy, and tobacco smoking on the development of asthma-like symptoms in asymptomatic teenagers. Chest 2000; 117: 1-9.

18. Kim Y, Kim SH, Tak YJ, et al. High prevalence of current asthma and active smoking effect among the elderly. Clin Exp Allergy 2002; 32: 1706-1712.

19. Toren K, Hermansson B. Incidence rate of adult-onset asthma in relation to age, sex, atopy and smoking: a Swedish population-based study of 15813 adults. Int J Tuberc Lung Dis 1999; 3: 192-197.

20. Vesterinen E, Kaprio J, Koskenvuo M. Prospective study of asthma in relation to smoking habits among 14729 adults. Thorax 1988; 43: 534-539.

21. Troisi R, Speizer F, Rosner B, Trichopoulos D, Willet W. Cigarette smoking and incidence of chronic bronchitis and asthma in women. Chest 1995; 108: 1557-1561.

22. Wang ZCC, Niu T, Wu D, et al. Association of asthma with beta $_{2}$-adrenergic receptor gene polymorphism and cigarette smoking. Am J Respir Crit Care Med 2001; 163: 1404-1409.

23. Raherison C, Baldi I, Tunon De Lara J, Taytard A, Annesi-Maesano I. Asthma phenotypes according to the timing of smoking onset in young adults. Int $J$ Tuberc Lung Dis 2003; 7: 84-92.

24. Gallefoss F, Bakke P. Does smoking affect the outcome of patient education and self management in asthmatics? Patient Educ Couns 2003; 49: 91-97.

25. Higenbottam T, Feyeraband C, Clark T. Cigarette smoking in asthma. Br J Dis Chest 1980; 74: 279-284.

26. Jensen E, Dahl R, Steffensen F. Bronchial reactivity to cigarette smoke; relation to lung function, respiratory symptoms, serum-immunoglobulin E and blood eosinophil and leukocyte counts. Respir Med 2000; 94: 119-127.

27. Oosterhoff Y, Jansen M, Postma D, Koeter G. Airway responsiveness to adenosine $5^{\prime}$-monophoshate in smokers and nonsmokers with atopic asthma. J Allergy Clin Immunol 1993; 92: 773-776.

28. Cassino C, Ito K, Bader I, Ciotoli G, Thurston G, Reibman J. Cigarette smoking and ozone-associated emergency department use for asthma by adults in New York City. Am J Respir Crit Care Med 1999; 159: 1773-1779.

29. Barr R, Woodruff P, Clark S, Camargo C. Sudden-onset asthma exacerbations: clinical features, response to therapy, and 2-week follow-up. Eur Respir J 2000; 15: 266-273.

30. Prescott E, Lange P, Vestbo J. Effect of gender on hospital admissions for asthma and prevalence of self-reported asthma: a prospective study based on a sample of the general population. Thorax 1997; 52: 287-289.

31. Rasmussen F, Taylor D, Flannery E, et al. Risk factors for hospital admissions for asthma from children to young adulthood: a longitudinal population study. J Allergy Clin Immunol 2002; 110: 220-227.

32. LeSon S, Gershwin M. Risk factors for asthmatic patients requiring intubation. III. Observations in young adults. J Asthma 1996; 33: 27-35.

33. Mitchell I, Tough S, Semple L, Green F, Hessel P. Near-fatal asthma: a population-based study of risk factors. Chest 2002; 121: 1407-1413.

34. Ryan G, Musk A, Perera D, Stock H, Knight J, Hobbs M. Risk factors for death in patients admitted to hospital with asthma: a follow-up study. Aust N Z J Med 1991; 21: 681685.

35. Marquette C, Saulnier F, Leroy $\mathrm{O}$, et al. Long-term prognosis of near-fatal asthma. Am Rev Respir Dis 1992; 146: 76-81.

36. Lange P, Parner J, Vestbo J, Schnohr P, Jensen G. A 15 year follow-up study of ventilatory function in adults with asthma. N Engl J Med 1998; 339: 1194-1200. 
37. Global initiative for asthma: global strategy for asthma management and prevention. Bethesda, MD, 1995 NHLBI/ WHO Report 95-3695.

38. Kerstjens H, Overbeek S, Schouten J, Brand P, Postma D. Airways hyperresponsiveness, bronchodilator response, allergy and smoking predict improvement in FEV1 during long-term inhaled corticosteroid treatment. Eur Respir $J$ 1993; 6: 868-876.

39. Pedersen B, Dahl R, Karlstrom R, Peterson C, Venge P. Eosinophil and neutrophil activity in asthma in one-year trial with inhaled budesonide. Am J Respir Crit Care Med 1996; 153: 1519-1529.

40. Chalmers GW, Macleod KJ, Little SA, Thomson LJ, McSharry CP, Thomson NC. Influence of cigarette smoking on inhaled corticosteroid treatment in mild asthma. Thorax 2002; 57: 226-230.

41. Chaudhuri R, Livingston E, McMahon AD, Thomson L, Borland W, Thomson NC. Cigarette smoking impairs the therapeutic response to oral corticosteroids in chronic asthma. Am J Respir Crit Care Med 2003; 168: 1308-1311.

42. Convery R, Leitch D, Bromly C, Ward R, Bartlett G, Hendrick D. Effect of inhaled fluticasone proprionate on airway responsiveness in treatment-naive individuals: a lesser benefit in females. Eur Respir J 2000; 15: 19-24.

43. Meijer R, Postma D, Kauffman HF, Arends LR, Koeter GH, Kerstjens HA. Accuracy of eosinophils and eosinophil cationic protein to predict steroid improvement in asthma. Clin Exp Allergy 2002; 32: 1096-1103.

44. Burge P, Calverley PMA, Jones PW, Spencer S, Anderson J. Prednisolone response in patients with chronic obstructive pulmonary disease: results from the ISOLDE study. Thorax 2003; 58: 654-658.

45. Chalmers G, MacLeod K, Thomson L, Little S, McSharry C, Thomson N. Smoking and airway inflammation in patients with mild asthma. Chest 2001; 120: 1917-1922.

46. Zevin S, Benowitz N. Drug interactions with tobacco smoking. Clin Pharmacokinetics 1999; 36: 425-438.

47. Marks G, Burney P, Premaratne U, Simpson J, Webb J. Asthma in Greenwich, UK: impact of the disease and current management practices. Eur Respir J 1997; 10: 1224-1229.

48. Radeos M, Leak L, Hanrahan J, Clark S, Camargo C. Risk factors for lack of asthma self-management knowledge among ED patients not on inhaled steroids. Am J Emerg Med 2001; 19: 253-259.

49. Abdulwadud O, Abramson M, Forbes A, et al. Attendance at an asthma educational intervention: characteristics of participants and non-participants. Respir Med 1997; 91: 524-529.

50. Yoon R, McKenzie D, Miles D, Bauman A. Characteristics of attenders and non-attenders at an asthma education programme. Thorax 1991; 46: 886-890.

51. Gallefoss F, Bakke P, Wang I, Gilja M, Gulsvik A. Smoking status, disease duration, and educational level in females, are related to asthma school participation. Eur Respir $J$ 2000; 15 : 1022-1025.

52. Wakefields M, Ruffin R, Campbell D, Roberts L, Wilson D. Smoking-related beliefs and behaviour among adults with asthma in a representative population sample. Aust $N Z$ $J$ Med 1995; 25: 12-17.

53. Eisner M, Yelin E, Katz P, Shoiboski S, Henke J, Blanc PD. Predictors of cigarette smoking and smoking cessation among adults with asthma. Am J Public Health 2000; 90: 1307-1311.

54. West R, McNeill A, Raw M. Smoking cessation guidelines for health professionals: an update. Thorax 2000; 55: 987999.

55. Report of the Surgeon General. The health benefits of smoking cessation. Bethesda, USA Public Health Services (Office on Smoking and Health), 1990; pp. 1-627.

56. Willemse B, Postma DS, Timens W, et al. The impact of smoking cessation on respiratory symptoms, lung function, airway hyperresponsiveness and inflammation. Eur Respir $J$ 2004; 23: $464-476$.
57. Anthonisen NR, Connett JE, Murray RP. Smoking and lung function of lung health study participants after 11 years. Am J Respir Crit Care Med 2002; 166: 675-679.

58. Hillerdahl G, Rylander R. Asthma and smoking cessation. Clin Allergy 1984; 14: 45-47.

59. Fennerty A, Banks J, Ebden P, Bevan C. The effect of cigarette withdrawal on asthmatics who smoke. Eur J Repir Dis 1987; 71: 395-399.

60. Godtfredsen N, Lange P, Prescott E, Osler M, Vestbo J. Changes in smoking habit and risk of asthma: a longitudinal population based study. Eur Respir $J$ 2001; 18: 549-554.

61. Saetta M, Turato G, Maestrell P, et al. Cellular and structural bases of chronic obstructive pulmonary disease. Am J Repir Crit Care Med 2001; 163: 1304-1309.

62. Jeffery P. Structural and inflammatory changes in COPD: a comparison with asthma. Thorax 1998; 53: 129-136.

63. Roth M, Arora A, Barsky S, Kleerup E, Simmons M, Tashkin D. Airway inflammation in young marijuana and tobacco smokers. Am J Respir Crit Care Med 1998; 157: 928-937.

64. Kuschner W, D'Alessandro A, Wong H, et al. Dosedependent cigarette smoking-related inflammatory responses in healthy adults. Eur Respir J 1996; 9: 1989-1994.

65. Di Stefano A, Capelli A, Lusuardi M, et al. Decreased T lymphocytes infiltration in bronchial biopsies of subjects with severe chronic obstructive pulmonary disease. Clin Exp Allergy 2001; 31: 893-902.

66. Lams B, Sousa A, Rees P, et al. Immunopathology of the small-airway submucosa in smokers with and without chronic obstructive pulmonary disease. Am J Respir Crit Care Med 1998; 158: 1518-1523.

67. Zhang X, Moilanen E, Lahti A, et al. Regulation of eosinophil apoptosis by nitric oxide: role of c-Jun-N-terminal kinase and signal transducer and activator of transcription 5 . J Allergy Clin Immunol 2003; 112: 93-101.

68. Assreuy J, Cunha F, Liew F, Moncada S. Feedback inhibition of nitric oxide synthase by nitric oxide. $\mathrm{Br} J$ Clin Pharmacol 1993; 108: 833-837.

69. Melgert BN, Postma DS, Geerlings M, et al. Short-term smoke exposure attenuates ovalbumin-induced airway inflammation in allergic mice. Am J Respir Cell Mol Biol 2004; 30: 880-885.

70. Sopori M, Kozak W. Immunomodulatory effects of cigarette smoke. J Neuroimmunol 1998; 83: 148-156.

71. Wang $\mathrm{H}, \mathrm{Yu} \mathrm{M}$, Ocham $\mathrm{M}$, et al. Nicotinic acetylcholine receptor 7 subunit is an essential regulator of inflammation. Nature 2003; 421: 348-388.

72. Seymour BW, Schelegle ES, Pinkerton KE, et al. Secondhand smoke increases bronchial hyperreactivity and eosinophilia in a murine model of allergic aspergillosis. Clin Dev Immunol 2003; 10: 35-42.

73. Seymour BW, Pinkerton KE, Friebertshauser KE, Coffman RL, Gershwin LJ. Second-hand smoke is an adjuvant for T helper-2 responses in a murine model of allergy. $J$ Immunol 1997; 159: 6169-6175.

74. Skold C, Blaschke E, Eklund A. Transient increases in albumin and hyaluronan in bronchoalveolar lavage fluid after quitting smoking: possible signs of reparative mechanisms. Respir Med 1996; 90: 523-529.

75. Turato G, Di Stefano P, Maestrelli P, et al. Effect of smoking cessation on airway inflammation in chronic bronchitis. Am J Respir Crit Care Med 1995; 152: 1262-1267.

76. Domagala-Kulawik J, Maskey-Warzechowska M, Kraszewska I, Chazan R. The cellular composition and macrophage phenotype in induced sputum in smokers and ex-smokers. Chest 2003; 123: 1054-1059.

77. McKay A, Komai-Koma M, MacLeod K, et al. Interleukin18 levels in induced sputum are reduced in asthmatic and normal smokers. Clin Exp Allergy 2004; 34: 904-910.

78. Van Hal P, Overbeek S, Hoogsteden H, et al. Eisosanoids and lipocortin-1 in BAL fluid in asthma: effects of smoking and inhaled corticosteroids. J Appl Physiol 1996; 81: 548555. 
79. Verleden G, Dupont L, Verpeut A, Demedts M. The effect of cigarette smoke on exhaled nitric oxide in mild steroid-naive asthmatics. Chest 1999; 116: 59-64.

80. White K, Marletta M. Nitric oxide synthase is a cytochrome P-450 type hemoprotein. Biochemistry 1992; 31: 6627-6631.

81. Robbins R, Millatmal T, Lassi K, Rennard S, Daughton D. Smoking cessation is associated with an increase in exhaled nitric oxide. Chest 1997; 112: 313-318.

82. MacNee W, Rahman I. Oxidants and antioxidants as therapeutic targets in chronic obstructive pulmonary disease. Am J Respir Crit Care Med 1999; 160: S58-S65.

83. Caramori G, Papi A. Oxidants and asthma. Thorax 2004; 59: 170-173.

84. Kwong K, Wu Z-X, Kashon M, et al. Chronic smoking enhances tachykinin synthesis and airway responsiveness in guinea pigs. Am J Respir Cell Mol Biol 2001; 25: 299305.

85. Carroll N, Perry S, Karkhanis A, et al. The airway longitudinal elastic fiber network and mucosal folding in patients with asthma. Am J Respir Crit Care Med 2000; 161: 244-248.

86. Little SA, Sproule MW, Cowan MD, et al. High resolution computed tomographic assessment of airway wall thickness in chronic asthma: reproducibility and relationship with lung function and severity. Thorax 2002; 57: 247-253.

87. Mclean AN, Sproule MW, Cowan MD, Thomson NC. High resolution computed tomography in asthma. Thorax 1998; 53: $308-314$

88. Lynch D, Newell J, Tschomper B, Cink T, Newman L, Bethel R. Uncomplicated asthma in adults: comparison of CT appearance of the lungs in asthmatic and healthy subjects. Radiology 1993; 188: 829-833.

89. Mitsunobu F, Ashida K, Hosaki Y, et al. Influence of longterm cigarette smoking on immunoglobin E-mediated allergy, pulmonary function, high-resolution computed tomography lung densitometry in elderly patients with asthma. Clin Exp Allergy 2004; 34: 59-64.

90. Sunyer J, Springer G, Jamieson B, et al. Effects of asthma on cell components in peripheral blood among smokers and non-smokers. Clin Exp Allergy 2003; 33: 1500-1505.

91. Halonnen M, Barbee R, Lebowitz M, Burrows B. An epidemiological study of the interrelationship of total serum immunoglobulin E, allergy skin tests reactivity and eosinophilia. J Allergy Clin Immunol 1982; 69: 221-228.

92. Taylor R, Gross E, Holland F, Pride N. Smoking, allergy and the differential white cell count. Thorax 1985; 40: 17-22.

93. Jensen E, Pedersen B, Narvestadt E, et al. Blood eosinophil and monocyte counts are related to smoking and lung function. Respir Med 1998; 92: 63-69.

94. Jarvis D, Chinn S, Lucynska C, Burney P. The association of smoking with sensitization to common environmental allergens: results from the European Community Health Survey. J Allergy Clin Immunol 1999; 104: 934-940.

95. Barnes PJ, Adcock IM. How do corticosteroids work in asthma? Ann Intern Med 2003; 139: 359-370.

96. Schaaf M, Cidlowski J. Molecular mechanisms of glucocorticoid action and resistance. J Steroid Biochem Mol Biol 2003; 83: 37-48.

97. Leung D, Bloom J. Update on glucocorticoid action and resistance. J Allergy Clin Immunol 2003; 111: 3-22.

98. Kino T, Chrousos G. Tissue-specific glucocorticoid resistance-hypersensitivity syndromes: multifactorial states of clinical importance. J Allergy Clin Immunol 2002; 109: 609-613.

99. Farrell RJ, Kelleher D. Glucocorticoid resistance in inflammatory bowel disease. J Endocrinol 2003; 178: 339-346.

100. Kennedy S, Elwood R, Wiggs B, Pare P, Hogg J. Increased airway mucosal permeability of smokers: relationship to airway reactivity. Am Rev Respir Dis 1984; 129: 143-148.

101. Ilowite J, Bennett W, Sheetz M, Groth M, Nierman D. Permeability of the bronchial mucosa to ${ }^{99 \mathrm{~m}} \mathrm{Tc}-\mathrm{DTPA}$ in asthma. Am Rev Respir Dis 1988; 139: 1139-1143.
102. Cerveri I, Accordini S, Corsico A, et al. Chronic cough and phlegm in young adults. Eur Respir $J$ 2003; 22: 413-417.

103. Rose J, Yurchak A, Meikle A, et al. Effect of smoking on prednisone, prednisolone, and dexamethasone pharmacokinetics. J Pharmacokinet Biopharm 1981; 9: 1-14.

104. Laustiola K, Lassilia R, Kaprio J, Koskenvuo M. Decreased beta-adrenergic receptor density and catecholamine response in male cigarette smokers: a study of monozygotic twin pairs discordant for smoking. Circulation 1988; 78: 1234-1240.

105. Laustiola K, Kotamaki M, Lassilia R, Kallioniemi O, Manninem V. Cigarette smoking alters sympathoadrenal regulation by decreasing the density of beta ${ }_{2}$-adrenoceptor: a study of monitoring smoking cessation. $J$ Cardiovasc Pharmacol 1991; 17: 923-938.

106. Barnes P. Scientific rationale for inhaled combination therapy with long-acting beta2-agonists and corticosteroids. Eur Respir J 2002; 19: 182-191.

107. Holt P. Immune and inflammatory function in cigarette smokers. Thorax 1987; 42: 241-249.

108. Floreani A, Rennard S. The role of cigarette smoke in the pathogenesis of asthma and as a trigger for acute symptoms. Curr Opin Pulm Med 1999; 5: 38-46.

109. Green RH, Brightling CE, Woltmann G, Parker D, Wardlaw AJ, Pavord ID. Analysis of induced sputum in adults with asthma: identification of subgroup with isolated sputum neutrophilia and poor response to inhaled corticosteroids. Thorax 2002; 57: 875-879.

110. Pizzichini M. Is sputum eosinophilia a good or poor predictor of benefit from inhaled corticosteroid therapy in asthma? Eur Respir J 2002; 20: 1359-1361.

111. Spahn J, Landwehr L, Nimmagadda S, Surs W, Leung D, Szefler S. Effects of glucocorticoids on lymphocyte activation in patients with steroid-sensitive and steroid-resistant asthma. J Allergy Clin Immunol 1996; 98: 1073-1079.

112. Costabel U, Bross $\mathrm{K}$, Reuter $\mathrm{C}$, et al. Alterations in immunoregulatory T-cell subsets in cigarette smokers: a phenotypic analysis of bronchoalveolar and blood lymphocytes. Chest 1986; 90: 39-44

113. Hattotuwa K, Gizycki M, Ansari T, Jeffrey P, Barnes N. The effects of inhaled fluticasone on airway inflammation in chronic obstructive pulmonary disease. Am J Respir Crit Care Med 2002; 165: 1592-1596.

114. Byron K, Varigos G, Wootton A. IL-4 production is increased in cigarette smokers. Clin Exp Immunol 1994; 95: 333-336.

115. Keatings V, Collins P, Scott D, Barnes P. Differences in interleukin- 8 and tumour necrosis factor- $\alpha$ in induced sputum from patients with chronic obstructive pulmonary disease and asthma. Am J Respir Crit Care Med 1996; 153: 530-534.

116. Churg A, Dai J, Changshi X, Wright J. Tumour necrosis factor- $\alpha$ is central to acute cigarette smoke-induced inflammation and connective tissue breakdown. Am J Respir Crit Care Med 2002; 166: 849-854.

117. Kam J, Szefler S, Surs W, Sher E, Leung D. Combination IL-2 and IL-4 reduces glucocorticoid receptor-binding affinity and $\mathrm{T}$ cell response to glucocorticoids. J Immunol 1993; 151: 3460-3466.

118. Franchimont D, Martens H, Hagelstein M-T, et al. Tumour necrosis factor alpha decreases, and interleukin-10 increases, the sensitivity of human monocytes to dexamethasone: potential regulation of the glucocorticoid receptor. $J$ Clin Endocrinol Metab 1999; 84: 2834-2839.

119. Hawrylowicz C, Richards D, Loke T-K, Corrigan C, Lee T. A defect in corticosteroid-induced IL-10 production in $\mathrm{T}$ lymphocytes from corticosteroid-resistant patients. J Allergy Clin Immunol 2002; 109: 369-370.

120. Takanashi S, Hasegawa Y, Kanehira Y, et al. Interleukin-10 level in sputum is reduced in bronchial asthma, COPD and smokers. Eur Respir J 1999; 14: 309-314.

121. Irusen E, Matthews J, Takahashi A, Barnes P, Chung K, Adcock I. p38 Mitogen-activated protein kinase-induced 
glucocorticoid receptor phosphorylation reduces its activity: role in steroid-insensitive asthma. J Allergy Clin Immunol 2002; 109: 649-657.

122. Norman V, Keith C. Nitrogen oxides in tobacco smoke. Nature 1965; 205: 915-916.

123. Galigniana MD, Piwien-Pilipuk G, Assreuy J. Inhibition of glucocorticoid receptor binding by nitric oxide. $\mathrm{Mol}$ Pharmacol 1999; 55: 317-323.

124. Kharitonov SBP. Nitric oxide, nitrotyrosine, and nitric oxide modulators in asthma and chronic obstructive pulmonary disease. Curr Allergy Asthma Rep 2003; 3: 121-129.

125. Hamid Q, Wenzel S, Hauk P, et al. Increased glucocorticoid receptor $\beta$ in the airway cells of glucocorticoid-insensitive asthma. Am J Respir Crit Care Med 1999; 159: 1600-1604.

126. Sousa A, Lane S, Cidlowski J, Staynov D, Lee T. Glucocorticoid resistance in asthma is associated with elevated in vivo expression of the glucocorticoid receptor beta-isoform. J Allergy Clin Immunol 2000; 105: 943-950.

127. Hauk P, Goleva E, Strickland I, et al. Increased glucocorticoid receptor beta expression converts mouse hybridoma cells to a corticosteroid-insensitive phenotype. Am J Respir Cell Mol Biol 2002; 27: 361-367.

128. Oakley RH, Jewell CM, Yudt MR, Bofetiado DM, Cidlowski JA. The dominant negative activity of the human glucocorticoid receptor beta isoform. Specificity and mechanisms of action. $J$ Biol Chem 1999; 274: 27857-27866.

129. Pujols L, Mullol J, Perez M, et al. Expression of the human glucocorticoid receptor alpha and beta isoforms in human respiratory epithelial cells and their regulation by dexamethasone. Am J Respir Cell Mol Biol 2001; 24: 49-57.

130. Leung D, Hamid Q, Vottero A, et al. Association of glucocorticoid insensitivity with increased expression of glucocortocoid receptor $\beta$. J Exp Med 1997; 186: 1567-1574.

131. Strickland I, Kisich K, Hauk PJ, et al. High constitutive glucocorticoid receptor beta in human neutrophils enables them to reduce their spontaneous rate of cell death in response to corticosteroids. J Exp Med 2001; 193: 585-594.

132. Webster J, Oakley R, Jewell C, Cidlowski J. Proinflammatory cytokines regulate human glucocorticoid receptor gene expression and lead to the accumulation of the dominant negative $\beta$ isoform: a mechanism for the generation of glucocorticoid resistance. Proc Natl Acad Sci USA 2001; 98: 6865-6870.

133. Verheggan $\mathrm{M}$, Adriaansen-Soeting $\mathrm{P}$, Berrevoets $\mathrm{C}$, et al. Glucocorticoid receptor expression in human bronchial epithelial cells: effects of smoking and COPD. Mediators Inflamm 1998; 7: 275-281.

134. Wang J, Manning B, Wu Q, Blankson S, Bouchier-Hayes D, Redmond H. Endotoxin/lipopolysaccharide activates NF- $\kappa$ B and enhances tumour cell adhesion and invasion through a $\beta 1$ integrin-dependent mechanism. J Immunol 2003; 170: 795-804

135. Di Stefano A, Caramori $\mathrm{G}$, Oates $\mathrm{T}$, et al. Increased expression of nuclear factor- $\kappa \mathrm{B}$ in bronchial biopsies from smokers and patients with COPD. Eur Respir J 2002; 20: $556-563$.

136. Bantel H, Schmitz M, Raible A, Gregor M, Schulze-Osthoff $\mathrm{K}$. Critical role of $\mathrm{NF}-\kappa \mathrm{B}$ and stress-activated protein kinases in steroid unresponsiveness. FASEB $J$ 2002; 16: 1832-1834.

137. Rahman I, MacNee W. Role of transcription factors in inflammatory lung disease. Thorax 1998; 53: 601-612.

138. Ito K, Caramori G, Lim S, et al. Expression and activity of histone deacetylases in human asthmatic airways. $\mathrm{Am}$ J Respir Crit Care Med 2002; 166: 392-396.
139. Ito K, Lim S, Caramori G, Chung K, Barnes P, Adcock I. Cigarette smoking reduces histone deacetylase 2 expression, enhances cytokine expression, and inhibits glucocorticoid actions in alveolar macrophages. FASEB J 2001; 15: 11101112.

140. Barnes PJ, Ito K, Adcock IM. Corticosteroid resistance in chronic obstructive pulmonary disease: inactivation of histone deacetylase. Lancet 2004; 363: 731-733.

141. Mochida-Nishimura K, Surewicz K, Cross J, et al. Differential activation of MAPK signalling pathways and nuclear factor- $\kappa \mathrm{B}$ in bronchoalveolar cells of smokers and nonsmokers. Mol Med 2001; 7: 177-185.

142. Calverley $\mathrm{P}$, Pauwels $\mathrm{R}$, Vestbo $\mathrm{J}$, et al. Combination salmeterol and fluticasone in the treatment of chronic obstructive pulmonary: a randomised controlled trial. Lancet 2003; 361: 449-456.

143. British Thoracic Society, Scottish Intercollegiate Guidelines Network. British guidelines on the management of asthma. Thorax 2003; 58: Suppl. 1, I1-I94

144. Johnson M, Rennard S. Alternative mechanisms for longacting $\beta_{2}$-adrenergic agonists in COPD. Chest 2001; 120 : $258-270$.

145. Ito K, Caramori G, Cosio M, Chung K, Adcock IM, Barnes P. A molecular mechanism of action of theophylline: induction of histone deacetylase to decrease inflammatory gene expression. Proc Natl Acad Sci USA 2002; 99: 89218926.

146. Ito K, Lim S, Chung KF, Barnes PJ, Adcock I. Theophylline enhances histone deacetylase activity and restores glucocorticoid function during oxidative stress. Am J Respir Crit Care Med 2002; 165: 625.

147. Compton C, Gubb J, Nieman R, et al. Cilomilast, a selective phosphodiesterase-4 inhibitor for treatment of patients with chronic obstructive pulmonary disease: a randomised, dose ranging study. Lancet 2001; 353: 265-270.

148. Caramori G, Adcock I. Pharmacology of airway inflammation in asthma and COPD. Pulm Pharmacol Ther 2003; 16 : 247-277.

149. Fauler J, Frolich J. Cigarette smoking stimulates cysteinyl leukotriene production in man. Eur J Clin Invest 1997; 27: 43-47.

150. Zhu J, Kilty I, Granger H, et al. Gene expression and immunolocalization of 15-lipoxygenase isozymes in the airway mucosa of smokers with chronic bronchitis. $\mathrm{Am}$ J Respir Cell Mol Biol 2002; 27: 666-677.

151. Leurs $\mathrm{R}$, Church $\mathrm{M}$, Taglialatela $\mathrm{M}$. $\mathrm{H}_{1}$-antihistamines: inverse agonism, anti-inflammatory actions and cardiac effects. Clin Exp Allergy 2002; 32: 489-498.

152. Creed $\mathrm{T}$, Norman M, Probert $\mathrm{C}$, et al. Basiliximab (anti-CD25) in combination with steroids may be an effective new treatment for steroid-resistant ulcerative colitis. Aliment Pharmacol Ther 2003; 18: 65-75.

153. Barnes PJ. Chronic obstructive pulmonary disease 12: new treatments for COPD. Thorax 2003; 58: 803-808.

154. Simon H, Seebach H, Ehmann R, Schmitz M. Clinical and immunological effects of low-dose IFN-alpha treatment in patients with corticosteroid-resistant asthma. Allergy 2003; 58: $1250-1255$.

155. Gratzl S, Palca A, Schmitz M, Hans-Uwe S. Treatment with IFN- $\alpha$ in corticosteroid unresponsive asthma. J Allergy Clin Immunol 2000; 105: 1035-1036.

156. Tsitoura DC, Rothman PB. Enhancement of MEK/ERK signaling promotes glucocorticoid resistance in CD4+ T cells. J Clin Invest 2004; 113: 619-627. 